\title{
Construction of Knowledge Test to Measure the Knowledge of Watershed Farmers towards Natural Resource Management Practices
}

\author{
P. Archana ${ }^{1 *}$, M. Jagan Mohan Reddy ${ }^{2}$, I. Sreenivasa Rao ${ }^{1}$ and G. E. Ch. Vidya Sagar ${ }^{1}$ \\ ${ }^{1}$ Department of Agricultural Extension, College of Agriculture, Rajendranagar, \\ PJTSAU, Hyderabad, 500030, Telangana, India \\ ${ }^{2}$ Principal Scientist and Programme Coordinator, KVK, Palem, Mahaboobnagar, \\ Telangana State, India \\ *Corresponding author
}

A B S T R A C T

Day by day the natural resources which are highly essential in agriculture like water, land, animal, vegetation are being degraded, eroded and dwindling. It is high time that the

\section{Keywords}

Watershed farmer; knowledge test; Natural Resource Management

Article Info

Accepted:

04 July 2017

Available Online:

10 September 2017 farmers should be sensitized and empowered to judicially utilize these resources. Management of natural resources beyond watershed areas, particularly in irrigated areas, is equally important. In fact, all the natural resources and the veritable water regimes irrigated and arid, semi-arid and wet rainfed areas are all interlinked and interdependent. Due to the non-availability of a proper test to measure the knowledge of watershed farmers towards Natural Resource Management practices, it was thought necessary to construct a test for the purpose. The study mainly contemplates to find out the knowledge of watershed farmers towards natural resource management practices. Keeping this in view, an attempt has been made to develop a test for measuring the knowledge of watershed farmers towards Natural Resource Management practices. Pertinent items were collected covering all aspects of Natural Resource Management practices. After getting jury opinion on the items of test index of item difficulty, index of item discrimination and index of item validity were worked out. To administer the knowledge test a respondent is given one mark for each correct answer and zero mark for each wrong answer. Thirty items were finally selected from 60 items.

\section{Introduction}

Natural Resources are the basic support system of life on Earth. Natural resources around the world are degrading and there is a great need to manage the common pool resources well. Livelihood of hundreds of millions of people, especially the rural poor will be seriously jeopardized.

Sustainable development of the society critically depends on natural resources and their management. Natural resources must be used in a way that meets today's needs, while conserving them for future generations. That will require action to develop capacities, from global to farm level, for their sustainable management and regulation (Berjesh and Ajay 2009, Reddy 1996).

Watershed development
conservation,
regeneration, and judicious 
utilization of natural resources. It aims to bring about an optimum balance between the demand and use of natural resources so that they remain sustainable over time. (Rao 1988, Chandran, 1991 and Doli, 2006.)

Knowledge was operationalised as extent of information known or possessed by the watershed farmers on selected NRM practices

\section{Materials and Methods}

\section{Collection of items}

The content of the test was composed of questions called items. A comprehensive list of knowledge questions on NRM practices in the study area were prepared by consulting officers of state department of Agriculture, officials of DWMA, books and discussion with agronomists, soil scientists and extension personnel of the University of Agricultural Sciences working in the study area.

\section{Selection of items}

The selection of items was done on the basis of the following criteria.

Response to items should promote thinking than routine memorization

They should differentiate the well informed watershed farmer from less informed and should have certain difficulty value.

The items included should cover all areas of knowledge about NRM practices.

By using above criteria, 60 items were selected for developing knowledge test, after editing carefully and by subjecting them to expert's endorsement. The experts consists Extension specialists, agronomists, soil scientists and WCC's project officers in the study area.

\section{Form of items}

The items selected for the construction of knowledge test on NRM practices were framed in the objective form viz., multiple choice, fill in the blanks and Yes or No. The particulars on the type of questions were furnished in the Table 2. (Dey and Sarkar (2011); Raju (2002); Eswarappa (1991); Iqbal (1991); Jaiswal, Purnadare and Yadappanwar (1982); Kadam, Patli and Haridwar (2001); Khan (1999). Krishnamohan (1992). Krishnamurthy (1993). Prasad (1990).

\section{Pre-testing}

The items selected for the knowledge test were pre-tested separately by administering the items to 90 watershed farmers. Care was taken to see that selection of matching sample of 90 watershed farmers from non-sampling area.

\section{Item analysis}

Item analysis was carried out by administering the pre-tested items to 30 watershed farmers.

Item analysis was carried out by determining the index of 'Item difficulty' and index of 'Item discrimination'. The 'Item difficulty' indicates the extent to which an item was difficult. The function of the item discrimination index was used to find out whether an item really discriminates a wellinformed watershed farmer from poorly informed respondent.

The data thus obtained was subjected for typical item analysis. The 60 test items were administered to each one of the 30 watershed farmers. The scores assigned were 'one' for correct answer and 'zero' for incorrect response. After computing the total scores were obtained for each of the 30 watershed 
farmers on 60 items. They were rank ordered. Based on which the watershed farmers were then divided into six equal groups. These groups were labeled as G1, G2, G3, G4, G5 and G6 with fifteen watershed farmers in each group. For the purpose of item analysis, middle two groups G3 and G4 were eliminated keeping only four extreme groups with high and low scores.

After getting the four extreme groups for item analysis, the responses for each of the items were subjected to calculate difficulty index, discrimination index and point biserial correlation as given below.

\section{Item difficulty index (P)}

The item difficulty index was worked out as the percentage of watershed farmer answering an item correctly. The assumption of the item difficulty index was that, the difficulty is linearly related to the level of watershed farmer's knowledge about NRM practices. The items with ' $\mathrm{P}$ ' values ranging from 0.20 to 0.80 were considered for the final selection of the knowledge test battery. Difficulty Index was computed by using the following formula and presented in Table 1 .

No. of respondents answering correctly Difficulty index $=$

Total no. of respondents

\section{Discrimination index (E 1/3)}

The second criterion for item selection was the item discrimination index indicated by ' $\mathrm{E}$ $1 / 3^{\prime}$ which is calculated by the formula.

$\mathrm{E}^{1 / 3}=\frac{(\mathrm{S} 1+\mathrm{S} 2)-(\mathrm{S} 5+\mathrm{S} 6)}{\mathrm{N} / 3}$

Where S1, S2, S5 and S6 are the frequencies of correct answers in groups G1, G2, G5 and
G6, respectively. $\mathrm{N}$ is the total number of watershed farmers of the sample selected for items analysis that is 30 . The value of the discrimination index for the knowledge items on NRM practices were presented in Table 1. The items with $\mathrm{E} 1 / 3$ value ranging from 0.2 to 0.8 were considered for the final selection of knowledge test.

\section{Point biserial correlation ( $\mathbf{r}$ pbis)}

The main aim of calculating Point biserial correlation (rpbis) was to work out the internal consistency of the items i.e., the relationship of the total score to a dichotomized answer to any given item. In a way, the validity power of the item was computed by the correlation of the individual item of preliminary knowledge test calculated by using following formula.

r pbis $=\frac{\mathrm{M}_{\mathrm{p}}-\mathrm{M}_{\mathrm{Q}}}{\text { S.D. }} \mathrm{J}_{\mathrm{PQ}}$

Where,

$\mathrm{r}$ pbis $=$ point biserial correlation coefficient

MP = Mean of the total scores of the respondents who answered the item correctly or

\section{Sum of total of XY \\ MP = -}

MQ = Mean of the total scores of the respondents who answered the item incorrectly or

$$
\begin{aligned}
& \mathrm{MQ}=\frac{\text { Sum total of } \mathrm{X}-\text { Sum total of XY }}{\text { Total number of wrong answers }} \\
& \text { S.D }=\text { Standard deviation of entire sample }
\end{aligned}
$$


Table.1 Respondent in four extreme groups

\begin{tabular}{|c|c|c|c|c|c|c|c|}
\hline \multirow{2}{*}{ S.No. } & \multicolumn{4}{|c|}{$\begin{array}{l}\text { Frequencies of correct answer of } \\
\text { respondents in four extreme groups }\end{array}$} & \multirow{2}{*}{$\begin{array}{l}\text { Difficulty } \\
\text { index }\end{array}$} & \multirow{2}{*}{$\begin{array}{l}\text { Discrimination } \\
\text { power }\end{array}$} & \multirow{2}{*}{ Rpbis } \\
\hline & G-1 & G-2 & G-5 & G-6 & & & \\
\hline 1. & 10 & 10 & 2 & 0 & 0.55 & 0.9 & $1.11^{*}$ \\
\hline 2. & 10 & 10 & 4 & 1 & 0.63 & 0.75 & $0.93 *$ \\
\hline 3. & 10 & 10 & 4 & 1 & 0.63 & 0.75 & $1.14 *$ \\
\hline 4. & 10 & 10 & 10 & 6 & 0.90 & 0.2 & $0.60^{*}$ \\
\hline 5. & 10 & 10 & 0 & 0 & 0.50 & 1 & $2.57 *$ \\
\hline 6. & 10 & 10 & 3 & 0 & 0.58 & 0.85 & $1.31 *$ \\
\hline 7. & 10 & 10 & 5 & 0 & 0.63 & 0.75 & $0.93 *$ \\
\hline 8. & 10 & 10 & 5 & 0 & 0.63 & 0.75 & $0.93 *$ \\
\hline 9. & 10 & 9 & 0 & 0 & 0.48 & 0.95 & NS \\
\hline 10. & 10 & 10 & 9 & 1 & 0.75 & 0.5 & $0.76^{*}$ \\
\hline 11. & 10 & 3 & 0 & 0 & 0.33 & 0.65 & $\mathrm{NS}$ \\
\hline 12. & 10 & 8 & 10 & 9 & 0.93 & -0.05 & $0.35^{* *}$ \\
\hline 13. & 10 & 9 & 3 & 0 & 0.55 & 0.8 & $\mathrm{NS}$ \\
\hline 14. & 10 & 10 & 0 & 0 & 0.50 & 1 & NS \\
\hline 15. & 0 & 5 & 8 & 10 & 0.58 & -0.65 & NS \\
\hline 16. & 10 & 10 & 8 & 2 & 0.75 & 0.5 & $0.76^{*}$ \\
\hline 17. & 10 & 10 & 6 & 2 & 0.70 & 0.6 & $0.80^{*}$ \\
\hline 18. & 10 & 10 & 7 & 5 & 0.80 & 0.4 & $0.61 *$ \\
\hline 19. & 10 & 10 & 9 & 7 & 0.90 & 0.2 & $0.56^{*}$ \\
\hline 20. & 8 & 7 & 3 & 1 & 0.48 & 0.55 & NS \\
\hline 21. & 10 & 10 & 7 & 2 & 0.73 & 0.55 & $0.79 *$ \\
\hline 22. & 10 & 10 & 5 & 3 & 0.70 & 0.6 & $0.85^{*}$ \\
\hline 23. & 10 & 10 & 7 & 8 & 0.88 & 0.25 & $0.58 *$ \\
\hline 24. & 10 & 10 & 0 & 0 & 0.50 & 1 & $\mathrm{NS}$ \\
\hline 25. & 8 & 3 & 4 & 2 & 0.43 & 0.25 & $\mathrm{NS}$ \\
\hline 26. & 10 & 9 & 2 & 0 & 0.53 & 0.85 & $2.82 *$ \\
\hline 27. & 9 & 3 & 0 & 0 & 0.30 & 0.6 & NS \\
\hline 28. & 10 & 5 & 2 & 0 & 0.43 & 0.65 & NS \\
\hline 29. & 5 & 9 & 10 & 10 & 0.85 & -0.3 & NS \\
\hline
\end{tabular}




\begin{tabular}{|c|c|c|c|c|c|c|c|}
\hline \multirow[t]{2}{*}{ S.No. } & \multicolumn{4}{|c|}{$\begin{array}{l}\text { Frequencies of correct answer of } \\
\text { respondents in four extreme groups }\end{array}$} & \multirow{2}{*}{$\begin{array}{l}\text { Difficulty } \\
\text { index }\end{array}$} & \multirow{2}{*}{$\begin{array}{l}\text { Discrimination } \\
\text { power }\end{array}$} & \multirow[t]{2}{*}{ Rpbis } \\
\hline & G-1 & G-2 & G-5 & G-6 & & & \\
\hline 30. & 9 & 9 & 10 & 8 & 0.90 & 0 & $0.40^{*}$ \\
\hline 31. & 10 & 3 & 0 & 0 & 0.33 & 0.65 & NS \\
\hline 32. & 10 & 3 & 0 & 0 & 0.33 & 0.65 & NS \\
\hline 33. & 8 & 6 & 0 & 0 & 0.35 & 0.7 & NS \\
\hline 34. & 6 & 6 & 0 & 0 & 0.30 & 0.6 & NS \\
\hline 35. & 10 & 10 & 8 & 0 & 0.70 & 0.6 & $0.82 *$ \\
\hline 36. & 8 & 7 & 4 & 5 & 0.60 & 0.3 & NS \\
\hline 37. & 6 & 2 & 0 & 0 & 0.20 & 0.4 & NS \\
\hline 38. & 6 & 2 & 0 & 0 & 0.20 & 0.4 & NS \\
\hline 39. & 5 & 1 & 0 & 0 & 0.15 & 0.3 & NS \\
\hline 40. & 1 & 1 & 0 & 0 & 0.05 & 0.1 & NS \\
\hline 41. & 2 & 2 & 0 & 0 & 0.10 & 0.2 & NS \\
\hline 42. & 1 & 1 & 0 & 0 & 0.05 & 0.1 & NS \\
\hline 43. & 10 & 10 & 0 & 0 & 0.50 & 1 & $2.57^{*}$ \\
\hline 44. & 2 & 0 & 0 & 2 & 0.10 & 0 & NS \\
\hline 45. & 3 & 0 & 2 & 1 & 0.15 & 0 & NS \\
\hline 46. & 1 & 1 & 0 & 0 & 0.05 & 0.1 & NS \\
\hline 47. & 9 & 4 & 0 & 3 & 0.40 & 0.5 & NS \\
\hline 48. & 10 & 10 & 4 & 1 & 0.63 & 0.75 & $1.02 *$ \\
\hline 49. & 10 & 10 & 3 & 0 & 0.58 & 0.85 & $1.67^{*}$ \\
\hline 50. & 10 & 8 & 9 & 4 & 0.78 & 0.25 & $0.76^{*}$ \\
\hline 51. & 9 & 10 & 9 & 7 & 0.88 & 0.15 & $0.58^{*}$ \\
\hline 52. & 10 & 3 & 0 & 0 & 0.33 & 0.65 & NS \\
\hline 53. & 10 & 10 & 9 & 5 & 0.85 & 0.3 & $0.65^{*}$ \\
\hline 54. & 10 & 10 & 0 & 0 & 0.50 & 1 & $2.57^{*}$ \\
\hline 55. & 10 & 10 & 7 & 7 & 0.85 & 0.3 & $0.62 *$ \\
\hline 56. & 10 & 8 & 0 & 0 & 0.45 & 0.9 & NS \\
\hline 57. & 10 & 10 & 4 & 1 & 0.63 & 0.75 & $1.02 *$ \\
\hline 58. & 10 & 6 & 0 & 0 & 0.40 & 0.8 & NS \\
\hline 59. & 9 & 2 & 0 & 0 & 0.28 & 0.55 & NS \\
\hline 60. & 10 & 10 & 7 & 7 & 0.85 & 0.3 & $0.62 *$ \\
\hline
\end{tabular}


Table. 2 Level of knowledge of watershed farmers towards nrm practices

\begin{tabular}{|c|c|c|c|}
\hline S.NO & Practice /technology used for Natural Resource Management & YES & NO \\
\hline 1 & $\begin{array}{l}\text { The important natural resource is: } \\
\text { A. soil B. water C. vegetation D. all }\end{array}$ & & \\
\hline 2 & $\begin{array}{l}\text { Watershed is: } \\
\text { A. small Area } \\
\text { B. specific area with common drainage point } \\
\text { C. area with nala D. no idea } \\
\end{array}$ & & \\
\hline 3 & $\begin{array}{l}\text { Integrated farming is beneficial for: } \\
\text { A. higher benefits } \\
\text { B. } \quad \text { sustaining the production } \\
\text { C. } \quad \text { efficient utilization of resources } \\
\text { D. } \quad \text { all }\end{array}$ & & \\
\hline 4 & $\begin{array}{l}\text { Natural resource management is possible only by the community participation } \\
\text { Yes/No }\end{array}$ & & \\
\hline 5 & Natural resource management is possible only by public budget Yes/No & & \\
\hline 6 & The excessive use of the natural resources is harmful. Yes/no & & \\
\hline 7 & $\begin{array}{l}\text { Soil is being eroded due to } \\
\text { A. rain water and wind } \\
\text { B. excessive/improper land leveling } \\
\text { C. A\&B } \\
\text { D. no idea }\end{array}$ & & \\
\hline 8 & $\begin{array}{l}\text { Bunds can be strengthened by: } \\
\text { A. planting grasses on it } \\
\text { B. } \quad \text { compacting the bund } \\
\text { C. } \quad \text { no idea } \\
\text { D. } \quad \text { A\&B } \\
\end{array}$ & & \\
\hline 9 & $\begin{array}{l}\text { Vegetation helps in conservation of soil by: } \\
\text { A. checking the erosion } \\
\text { B. addition of litter material } \\
\text { C. checking the speed of runoff } \\
\text { D. all }\end{array}$ & & \\
\hline 10 & $\begin{array}{l}\text { Live fencing in the field can be used for } \\
\text { A. to reduce soil erosion } \\
\text { B. } \quad \text { to reduce water loss } \\
\text { C. } \quad \text { A\& D } \\
\text { D. } \quad \text { protect the crops from animals } \\
\end{array}$ & & \\
\hline 11 & $\begin{array}{l}\text { Loose boulder structure and can be used for............... } \\
\text { A. to reduce soil erosion } \\
\text { B. } \quad \text { to reduce water velocity } \\
\text { C. to increase moisture in the soil } \\
\text { D. } \quad \text { all the above }\end{array}$ & & \\
\hline 12 & 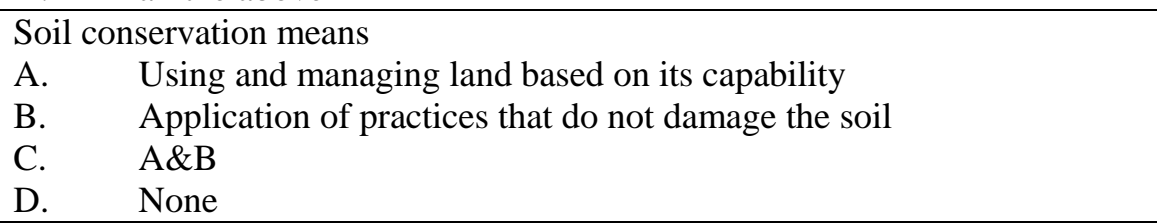 & & \\
\hline 13 & $\begin{array}{l}\text { Removing the trees leads to: } \\
\text { A. high erosion } \\
\text { B. no effect } \\
\text { C. reduce fertility }\end{array}$ & & \\
\hline
\end{tabular}




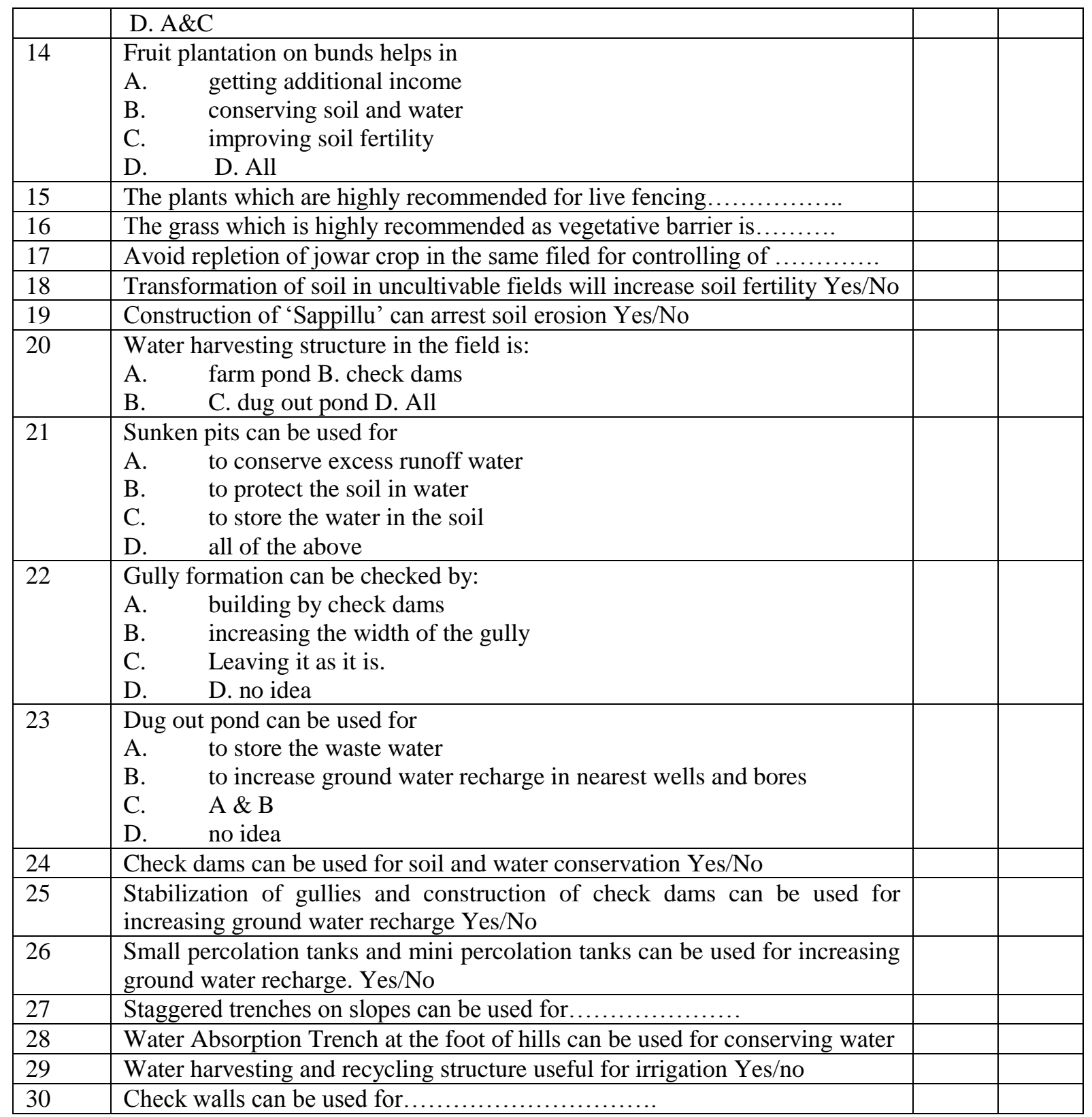

$\mathrm{P}=$ Proportion of respondents giving correct answer to the item

Total number of correct answers

$\mathrm{P}=$

Total number of respondents

$\mathrm{Q}=$ Proportion of respondents giving incorrect answer to the item

$\mathrm{Q}=1-\mathrm{P}$

$\mathrm{X}=$ Total score of the respondent for all items
$\mathrm{Y}=$ Response of the individual for the items

$\mathrm{XY}=$ Total score of the respondent multiplied by the response of the individual to the item

Items having significant point bi serial correlation at $1 \%$ and $5 \%$ level were selected for final knowledge test and are presented in Table 1.

\section{Representativeness of the test}

Care was taken to see that the test items 
selected finally covered the entire universe of the relevant behavioural aspects of watershed farmer's knowledge about NRM practices..

\section{Selection of the items}

Out of 60 items, 30 items were finally selected based on;

Items with difficulty level indices ranging from 0.20 to 0.80 .

Items with discrimination indices ranging from 0.20 to 0.80 .

Items having significant point biserial correlation either at 1 percent or 5 percent level.

Thus, the finally selected knowledge items comprising 3 types of questions i.e. multiple choice, fill in the blanks and Yes or No, totaling to 30 items of test battery on knowledge of NRM Practices.

The final knowledge test items selected for the test are given in the interview schedule furnished in Table 2.

\section{Reliability of the test}

The test was administered to 30 watershed farmers separately with an interval of 15 days. The two sets knowledge scores obtained by the watershed farmers were correlated. The correlation co-efficient $(\mathrm{r}=0.82)$ was highly significant indicating a high degree of dependability of the instrument for measuring knowledge of watershed farmers

\section{Validity of the test}

Knowledge test developed on NRM practices was subjected to content and construct validity. The construct validity of the test items was tested by the method of point biserial correlation (rpbis). The items have significant values at $1 \%$ and $5 \%$ level indicated the construct validity of the test.

The content validity of knowledge test was derived a long list of test items representing the whole universe of NRM practices collected from various sources as discussed earlier. It was assumed that the score obtained by administering the knowledge test of this study measures level of knowledge of watershed farmers towards NRM practices.

Thus the knowledge test developed in the present study can measure the knowledge of watershed farmers towards NRM practices as it showed the greater degree of reliability and validity.

\section{Administration of the test}

All the 30 items in the knowledge test read out to the respondents after establishing rapport with them. The respondents were asked to answer the items by themselves.

Following are the statements on level of knowledge of watershed farmers towards NRM. Please give your response to these statements on two point continuum. i.e. Yes and No with a tick $(\sqrt{ })$ mark

\section{References}

Berjesh, A and Ajay, K. 2009. Knowledge of farmers about soil and rainwater conservation technology and its determinants. Agriculture Science Digest. 29(4): 283-286.

Chandran, K.N. 1991. A critical analysis of agriculture technology utilization in Maheswaram watershed project in Ranga Reddy district of Andhra Pradesh. M.Sc. (Ag.) Thesis. Acharya N.G. Ranga Agricultural University, Hyderabad, India.

Dey, P and Sarkar, A.K. 2011. Revisiting indigenous farming knowledge of Jharkhand (India) for conservation of natural resources and combating climate change. (Special Issue: 
Traditional knowledge in disaster prediction/forecasting, management and climate change.) Indian Journal of Traditional Knowledge. 10(1):71-79.

Doli, S. 2006. Sustainability of natural resource management in watershed development project. Ph.D Thesis. University of Agricultural Sciences, Dharwad, India.

Eswarappa, G. 1991. An analysis of coordination and some management aspects of watershed development programme in Karnataka. Ph. $D$ Thesis. Andhra Agriculture University, Hyderabad, India.

Iqbal, M. 1991. A study on the impact of watershed development programme in Nalgonda district of Andhra Pradesh. M.Sc. (Ag.) Thesis. Andhra Agriculture University, Hyderabad, India.

Jaiswal, N.K., Purnadare, A.P and Yadappanwar, A.V. 1982. Planning and management of watersheds under Drought Prone Area Programme. Journal of Rural Development. 4:739.

Kadam, J.R., Patli, V.G and Haridwar, D.P. 2001. Knowledge and adoption of soil and water conservation practices in watershed development project. Maharastra Journal of Extension Education. 20:138-140.

Khan, M.S. 1999. Critical analysis of eco-friendly technologies in rice cultivation. A study in an adopted village-kondubhotlopalem. M.Sc. (Ag.) Thesis. Acharya N.G. Ranga Agricultural University, Hyderabad, India.

Krishnamohan, R. 1992. Impact of social forestry programme on rural beneficiaries in Chittor district of Andhra Pradesh. M.Sc. (Ag.) Thesis. Andhra Agriculture University,
Hyderabad, India.

Krishnamurthy, M. 1993. A study on adoption behaviour of beneficiaries towards recommended practices of watershed development programme in Ananthpur district of Andhra Pradesh. M.Sc. (Ag.) Thesis. Andhra Agriculture University, Hyderabad, India.

Prasad, K. 1990. A study on knowledge and adoption behaviuor of farmers towards recommended practices in Yerracheruvu model watershed development programme in Anatapur district of Andhra Pradesh. M.Sc. (Ag.) Thesis. Andhra Agriculture University, Hyderabad, India.

Raju, A. 2002. Analysis of selected factors responsible for sustainability of major crops production in a watershed area as perceived by farmers in Medak district of Andhra Pradesh. M.Sc. (Ag.) Thesis. Acharya N.G. Ranga Agricultural University, Hyderabad, India.

Rao, D. 1988. Impact of improved dryland agricultural technology in Chevella and Potuulabogunda model watershed development project in Jogipet taluk of Medak district in Andhra Pradesh. M.Sc. (Ag.) Thesis. Acharya N.G. Ranga Agricultural University, Hyderabad, India.

Reddy, C.V.G. 1996. An analysis of people participation in watershed development programme in Andhra Pradesh. Ph.D. Thesis. Acharya N.G. Ranga Agricultural University, Hyderabad, India.

\section{How to cite this article:}

Archana, P., M. Jagan Mohan Reddy, I. Sreenivasa Rao and Vidya Sagar, G.E.Ch. 2017. Construction of Knowledge Test to Measure the Knowledge of Watershed Farmers towards Natural Resource Management Practices. Int.J.Curr.Microbiol.App.Sci. 6(9): 81-89. doi: https://doi.org/10.20546/ijcmas.2017.609.009 